\title{
USING ANTCONC SOFTWARE AS ENGLISH LEARNING MEDIA: THE STUDENTS' PERCEPTION
}

\author{
Eri Ester Khairas \\ Civil Engineering Department, Politeknik Negeri Jakarta \\ E-mail: eri.esterkhairas@pnj.ac.id
}

\begin{abstract}
The use of techonology for a method in learning is rapidly developed and effect the students' learning process. This research is aimed to find out about the perception of college students about a learning method of English by using a software named AntConc. The data were collected through questionnaires divided into pre-questionnaire and postquestionnaire. Pre questionnaire was about students' perception towards AntConc software itself and the post questionnaire was about students' perception using the software. The respondents were 51 students of Engineering Department, Politeknik Negeri Jakarta.. This research shows that Antconc software can be an alternative method to enhance students learning of English by using some tools on its software.
\end{abstract}

Keywords: digital technology, corpus, English learning

\section{INTRODUCTION}

Broadly speaking, the evolution of technology changes all aspects in this world. Now, technology can be used for any purpose, especially for academic purposes. This evolution can be seen in the way of learning. In education world nowadays, the evolution of technology proves that it is one of the most effective learning media. According to Breyer (2008), learning media that using technology can increase students' motivation and decrease their level of boredom in learning. Students can use software for the learning process. So, it can help them to get more understanding about topic that being studied.

One of the learning media using technology is AntConc Software. Antconc software is a tool that can be used for students to understand the English learning. AntConc Software is a freeware and multiplatform tool for doing corpus and data-driven linguistic research (Anthony, 2012). Using corpus linguistics is an English learning by using corpora or 'banks' languages which are arranged and can be accessed through AntConc 3.4. Software.

AntConc Software is a general corpus analysis tool kit that can be applied on Windows, Linux and Macintosh system in the computer. This tool has been used by translators, language teacher and learners around the world. This tool is not merely analyzing English text but also other language such as Japanese, Korean, etc. One of the features in this tool is the Concordancer Tool which is used for seeing words used in a text.

Concordancer Tool is one main tools used in most corpus analysis software that can be used to facilitate the learning vocabulary for language learners. Sun \& Wang (2003) as cited by Anthony (2004) state that this tool has proven as an effective tool aid for second or foreign language acquisition and learning of vocabulary, collocations, grammar and writing styles. In AntConc, the Concordancer Tool is put into the main screen so the users can operate it directly. 


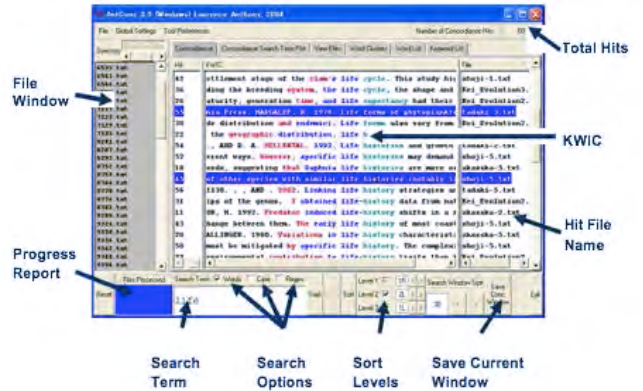

Figure 1. The Concordancer Tool features in AntConc (Anthony, 2004)

According to Anthony (2004) some features of Concordance Tool in AntConc are:

a. Search terms can be substrings, words, or phrases, and can be case sensitive or insensitive. They can be embedded with a wide range of wildcards, which the user can assign to any particular character or string of characters via a menu option

b. Search terms can be defined as full regular expressions (REGEX), offering the user access to extremely powerful and complex searches

c. Three levels of sorting of KWIC (Key Word In Context) lines are possible, with user definable highlight colors at each level

d. If a user clicks on any search term in the KWIC results display, the program will automatically open the View Files tool (described later) and show the search term hit in the original data file

e. The KWIC results display is divided into columns, in which the hit number, KWIC line, and file name are shown separately. As in all other tools, each column can be either displayed or hidden, and standard selection methods can be used to save data in the columns or rows to the clipboard or a text file.

Considering Antconc software as a tool that can be used for students to understand the English learning, this study would find the students' perception of using this corpus-based-application to improve their descriptive and analysis skills at their English learning. In order to find the answer, students were asked about AntConc Software, the advantages of using it and the intended courses as the learning materials..

\section{RESEARCH METHODOLOGY Participants and Instruments}

The participants of this research are students of Engineering Department at Politeknik Negeri Jakarta. The respodents are represented by 51 respondents. 23 of students who are studying English five at their fifth semester of study, are given tutorial of learning English using antConc Software. The reason of taking these students is because they have taken four semesters of English that they are representative for practicing the use of AntConc application as the learning media. This research is conducted through questionnaires. The questionnaire is carried out in two parts (prequestionnaire and postal questionnaire). The pre-questionnaire is filled by 51 respondents - asking about students 'understanding of the AntConc Software and its functions, and students' opninion about the AntConc function as a learning tool. The use of questionnaire aims to find the perception of undergraduate students at Polytechnic about a learning method of English using the AntConc Software Application.

The second questionnaire is a postquestionnaire filled by 23 respondents who have been given a tutorial for using the software. This survey includes several questions to measure the use of the AntConc Software Application as an English learning method. The questionnaire also includes questions about the intended courses of learning material through the AntConc Software Application as a tool for learning ESP (English for Specific Purposes) because the corpus can made based on the learning purposes; and the beneficial of this software in the learning process. 


\section{Data Collection and Analysis}

The data were collected in two times. The first data got from the respondents before giving tutorial of AntConc Software, but simply giving a brief description about the software. After the first part of the questionnaire (prequestionnaire) is analyzed and the intended respondents were given tutorial and use the software, then the second part of the questionnaire (post-questionnaire) was given, it aims to get the final perception of students after having tutorials and using AntConc Software.

Questionnaire data analysis aims to express the perception of Polytechnic undergraduate students about AntConc Software as a tool to improve students at English learning. The questionnaire were given through google form surveys. After quantitative data were collected from google form surveys. Analysis was done calculating the frequency and percentage of each question. Then the conclusion was made based on the result.

\section{RESULT AND DISCUSSION}

The following shows the results of the data analysis:

a. The Introduction of AntConc Software Application to Respondents

Based on the pre-questionnaire that has been given to students, the results show that from $100 \%$ of respondents, $86.3 \%$ still don't know about the AntConc Software Application. 58.8\% have understood the function of the software after having read the brief explanation about AntConc., but 7.8\% answered that they still don't understand about the AntConc Software Application.
Graph 1. Students Perception To The Benefits Of Antconc Software Application

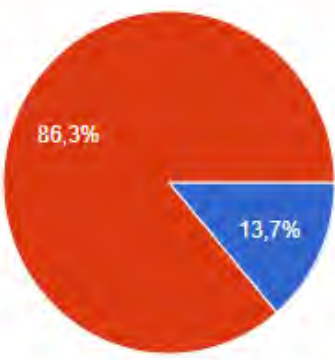

Respondents who already know AntConc Software Application are then given questions related to whether they can operate the software or not. Based on seven respondents who already know this software, there are nine people or $17.6 \%$ who can operate it and four of them have difficulty at operating it. But, 42 people or 82.4\% can’t operate it.

b. Students' Perceptions toward AntConc Software Application

After the AntConc Software Application explained, respondents are given questions related to the benefits of the software if it is used as a learning model. Based on the results received, $41.3 \%$ respondents answer that it is very useful, $51 \%$ said that it is useful enough, $4 \%$ said that it is less useful and $1.9 \%$ said it isn't useful.

Table I. The Student Perception About Benefits Of Antconc Software Application

\begin{tabular}{lcc}
\hline $\begin{array}{c}\text { Level of } \\
\text { Effectiveness }\end{array}$ & Respondents & Percentage \\
\hline Very Useful & 22 people & $43,10 \%$ \\
Quite Useful & 26 people & $51 \%$ \\
Less Useful & 2 people & $4 \%$ \\
Not Useful & 1 person & $1 \%$ \\
$\quad$ Total & 51 people & $100 \%$ \\
\hline
\end{tabular}

c. Students' Suggestions for Learning Materials Using AntConc Software Application.

From fifty one respondents who answered the pre-questionnaire and being asked to give suggestions regarding the learning materials that would be presented 
through the AntConc Software Application. The pre-questionnaire results shows that $78.4 \%$ of respondents choose part of speech, $90.2 \%$ choose sentence construction, $80.4 \%$ choose sentence type, $64.7 \%$ choose collocation, $78.4 \%$ choose vocabulary, and $68.6 \%$ choose sentence voice materials.

Graph 2. Students' Suggestions For Learning Materials

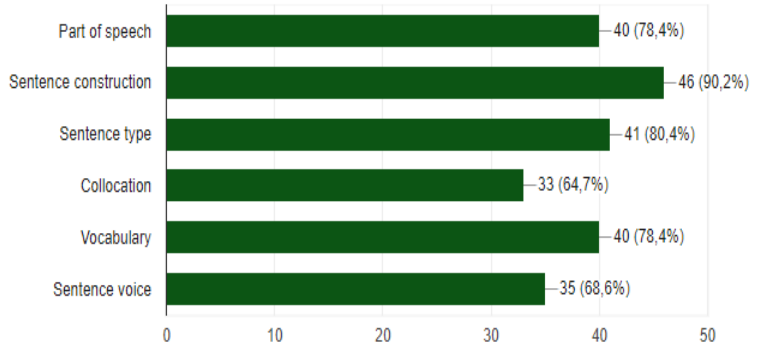

d. The Student Perception after Using the AntConc Software Application

After the students filled out the prequestionnaire, twenty three students as the respondents were then explained a tutorial on using the AntConc Software Application. After they finished the tutorial, they were given a postquestionnaire to find out how students' perceptions toward the learning model using the AntConc Software Application.

Based on the post-questionnaire results, from twenty three respondents, fourteen respondents or $60.9 \%$ strongly agree and nine respondents or $39.1 \%$ agree that the use of the AntConc Software application is very useful as a learning method.

Graph 3. The Students Perception To Antconc Software Application After Tutorial
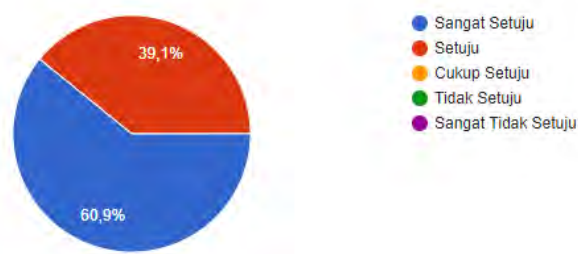

As many as fourteen (60.9\%) respondents strongly agree that AntConc is a proper tool for English for Specific
Purposes (ESP) learning because it can be used to save corpus based on its field of study. While, nine ( $39.1 \%$ ) others agree.

\section{Graph 4. Antconc As Esp Learning Method}

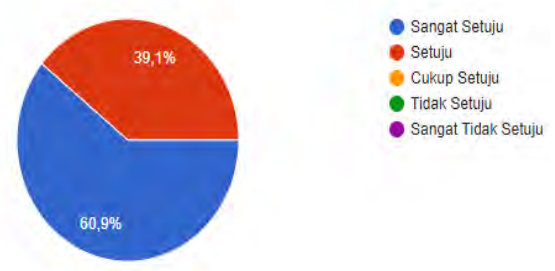

The $4^{\text {th }}$ graph shows that from the total respondents, sixteen(60.9\%) students strongly agree and seven (39.1\%) others agree that using AntConc software as a learning tool can improve their learning creativities because it can be used in various forms of exercises.

Graph 5. Antconc As A Learning Method Improves Learning Creativities

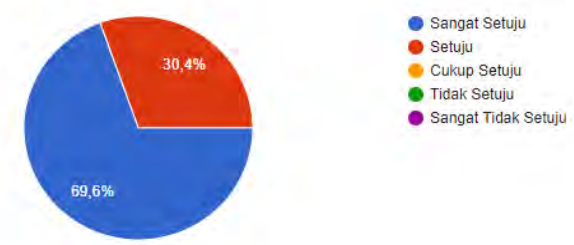

The following graph shows that from all respondents, fifteen (65.2\%) respondents strongly agree and eight others (34.8\%) agree that doing exercises using AntConc can improve their reading skills because AntConc Software presents a searchable word, in text form.

Graph 6. Antconc As A Learning Method Improves Reading Ability
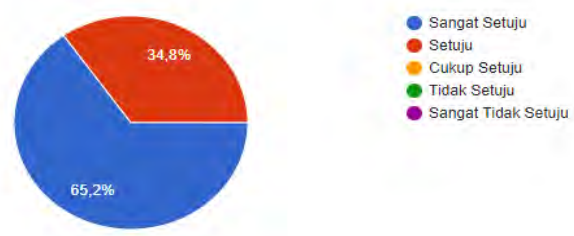

As many as fifteen (65.2\%) respondents strongly agree and eight (34.5\%)others agree that doing exercises using AntConc can increase part of 
speech because the AntConc Software can display one word such as 'verb' in various forms of 'verbs' in various sentence structures.

Graph 7. Antconc As A Learning Method Increases Knowledge About Part Of Speech

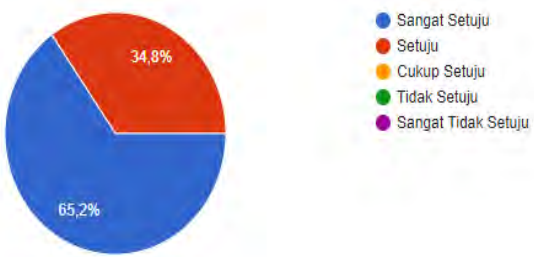

Concerning that the use AnctConc Software can gain their vocabulary, as much fifteen (65.2\%) respondents strongly agree and eight (34.6\%) others agree that the capabality of AntConc Software saving the authentic materials as the corpus of engineering e-books to be used as a learning media for vocabulary, gain their vocabulary of English engineering .

Graph 8. Antconc As A Learning Method Gains Vocabulary In Engineering Terms
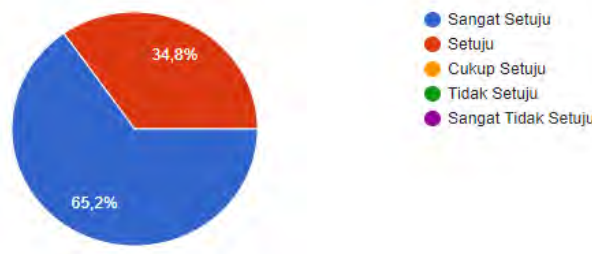

Eleven (47.8\%) respondents said strongly agree and twelve (52.2\%) others agreed that AntConc can be used to study types of sentences because the text from the corpus appears in various sentence structures.

Graph 9. Antconc As A Learning Method Used To Learn Sentence Types

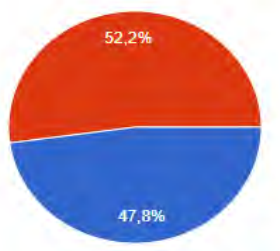

Fourteen (52.2\%) respondents said that they strongly agree and eight $(47.7 \%)$ others agree, and one $(0.1 \%)$ respondent said quite agree that doing exercises using authentic text from the corpus that appears in active and passive sentences can increase understanding of the use of active and passive English sentences.

Graph 10. Antconc As A Learning Method Improves Comprehension Of Using Active And Passive Constructions In English
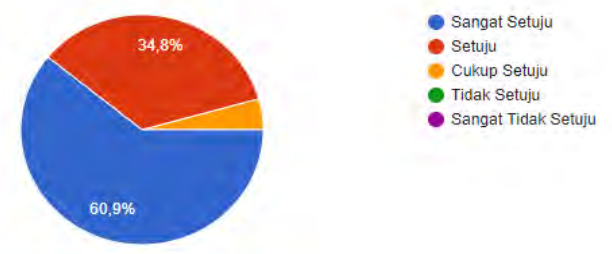

\section{CONCLUSION RECOMMENDATION}

AND

Form the findings and discussion result of pre-questionnaire and postquestionnaire, it is concluded that the AntConc Software Application is one of the useful learning methods. The AntConc Software application can be used in various fields of study, especially in engineering field. This software can be used as a learning model that utilizes the technology that is currently in evolution. In the AntConc Software Application, students can be better at understanding and improve the learning process according to their needs.

Therefore, it is highly recommended to apply the antconc software as the English learning media that the learners can use authentic materials from corpus.

\section{ACKNOWLEDGEMENT}

This work was supported by DIPA Politeknik Negeri Jakarta (grant number 700/PL3.18/PNJ/2018). 


\section{REFFERENCES}

Altiner, C., (2015), Perceptions of Undergraduate Students about Sychronous Video Conference-based English Course. Procedia Social and Behavioral Sciences. 627 - 633

Anthony, L. (2004). AntConc: A Learner and Classroom Friendly, MultiPlatfrom Corpus Analysis Toolkit. An Interactive Workshop on Language eLearning $7-13$

Biber D. et al. (2007). Longman grammar of spoken and written English. Essex: Pearson Education Limited,

Boulton, A. (2010).Data-Driven Learning: Taking the computer out of the equation. Language Learning, 60(3). 534-572,

Cruse, Alan, (2016). Meaning in Language. New York: Oxford University Press

Crystal, David, (2004).The Cambridge Encyclopedia of the English Language. Great Britain: Cambridge University Press.

Murcia-Celce, Marianne and Diane Larsen-Freeman, 1999. The Grammar Book:An ESL/EFL Teacher's Course.

O’Grady, William et al. (1996). Contemporary Linguistics An Introduction. Copp Clark Pitman Ltd.

Quirk, R. Sidney Greenbaum, Geoffrey Leech, Jan Savartvik. (1985). Comprehensive Grammar of English Language. London: Longman.

Rapp, R. (2001). The Computation of Word Associations: Comparing Syntagmatic and Paradigmatic Approaches. Information Processing \& Management , 28 (3), 317-332. 